\title{
ANALYSIS OF CONTRACTOR'S SELECTION CRITERIA IN RAILWAY PROJECTS
}

\begin{abstract}
A. LEŚNIAK ${ }^{1}$, F. JANOWIEC ${ }^{2}$
Particular diligence in the preparation of documentation and conducting a tender procedure for construction works must be made by public contracting entities, who are subject to additional restrictions. In Poland, the largest public contracting entities are the sectoral ones. These are the entities (defined in Art. 3 of the Public Procurement Law Act) operating in the sectors of water management, energy, transport and postal services. The paper presents the analysis of tender offers for the execution of construction works or design and execution of construction works related to the reconstruction, construction and revitalization of railway lines, announced after the amendment to the Public Procurement Law on June 22, 2016. The considered examples are selected tender procedures covering the scope of construction and assembly works on railway lines throughout the country. The authors paid particular attention to the tender criteria applied and the requirements for the potential contractors for works in the field of railway infrastructure
\end{abstract}

Keywords: bidding criteria, public investor, railway infrastructure

\section{INTRODUCTION}

The basis for the execution of construction works is well-prepared project documentation. An equally important step is to select the contractor who, in accordance with the requirements of the contracting authority, will complete the construction works and will put the building into operation within the

\footnotetext{
${ }^{1}$ Ph.D., Eng., Cracow University of Technology, Faculty of Civil Engineering, Institute of Construction Management, Warszawska 24 st., 31-155 Cracow, Poland, e-mail: alesniak@13.pk.edu.pl

${ }^{2}$ M.Sc., Eng., Cracow University of Technology, Faculty of Civil Engineering, Institute of Construction Management, Warszawska 24 st., 31-155 Cracow, Poland
} 
specified time, the proposed price and the fulfilment of the assumed technical and functional requirements.

The method of selecting a construction contractor in Poland in the public procurement sector is governed by the Public Procurement Law of 29 January 2004, as amended [24]. Article 2 specifies that the contract for construction works should be understood as execution, or both the design and execution of works. Accordingly, a contracting entity can perform the construction project in two ways: the traditional form, called the design-bid-build, or design and build system [16].

Particular diligence in the preparation of documentation and conducting a tender procedure for construction works must be made by public contracting entities, who are subject to additional restrictions. The manner of conducting the tender procedure, as well as the content, both in terms of quantity and specification of tender documents, are described in the Public Procurement Law of January 29, 2004: (i.e. Journal of Laws of 2015, item 2164, as amended) hereinafter referred to as: the PPL Act [24].

Their most frequent mistakes made during the preparation of tender documentation and the possible consequences were presented and discussed in [7]. The contractor, in turn, faces the necessity of making a decision whether to take part in the tender and take the effort to prepare offers without being sure of winning. The decision to participate in the tender needs to be made carefully, considering the risk involved in any construction project $[4,5,11,12,19]$ as it affects the condition of the company and is an important aspect in its quest for success [13]. It is conditioned by many factors related to the company and the environment, as described in $[14,15]$.

In Poland, the largest public contracting entities are the sectoral ones. These are the entities (defined in Article 3 of the PPL Act) operating in the sectors of water management, energy, transport and postal services (including private ones), which award sectoral contracts as defined in Article 132 of the PPL Act. A representative of sector investors is, among others, the manager of the national railway network: PKP Polskie Linie Kolejowe S.A.

One of the most important statutory tasks of the company is commissioning and supervising the construction works carried out on the Polish railway network [23]. The allocation of funds earmarked for the construction of railways in Poland is closely related to the communication strategy of the state [21] and the European Union supporting the infrastructural development of the Member States [3]. The currently implemented perspective of the "National Rail Program until 2023" is expected to be the largest of the previous, and its cost is estimated at 67 billion PLN [22]. The planned investments are to make up for the long-term negligence in the railway infrastructure $[17,18,22]$, which is why it is so important to spend the entrusted funds appropriately. Railway investments are characterized by 
their distinctiveness in comparison to other construction works and are subject to many random factors, which have a significant impact on extending the deadline and increasing the planned cost [9,21]. Railway investments are complex undertakings, not only due to their organizational or legal nature. Additional difficulties include the complexity and uniqueness of railway contracts. A challenge for each of the parties to the investment process become such factors as: uniqueness of the investment (each construction (modernization) is unique), longevity of the construction (railway lines and their components are designed for many years of operation, even for more than 100 years), combination of various types of construction branches. Railway projects are large in scope and cause high investment costs, which generates the need for reliable management of risk factors also. The recommendations for risk management in the selected methodology and their usefulness in railway construction was evaluated in [8].

The purpose of the paper is to analyse tender offers for the execution of construction works or design and execution of construction works related to the reconstruction, construction and revitalization of railway lines, announced after the amendment to the Public Procurement Law on June 22, 2016 [25]. The considered examples are selected tender procedures announced by PKP PLK S.A., in 2016 - 2017, covering the scope of construction and assembly works on railway lines throughout the country. The authors paid particular attention to the tender criteria applied and the requirements for the potential contractors for works in the field of railway infrastructure.

\section{SELECTION OF TENDER PROCEEDINGS}

The considered group of tender proceedings concerned the ones for construction works in railway undertakings in which the ordering party was PKP PLK S.A., in 2016-2017. The analysis included 50 protocols from the opening of offers. They were downloaded from the contracting entities' websites, indicated in the public procurement award [6]. In addition, the following criteria were taken into consideration when selecting the procedures for the analysis:

- Opening of envelopes in a tender for construction works took place on the following days: 1.08.2016-30.03.2017.

- The announcement of the order was announced in an unlimited or restricted tender procedure.

- The investor's investment budget for a minimum of PLN 1,000,000.00 gross.

- The scope of construction works contained at least: construction, reconstruction, modernization of the track system, or track bed, on any long section of the railway road, which is managed by PKP PLK S.A. 
The characteristics of selected procedures are presented in Table 1. It shows that $88 \%$ of the analysed proceedings concerned orders involving the design and execution of construction works (design \& build system).

Table 1. Characteristics of the proceedings discussed

\begin{tabular}{|c|c|c|c|}
\hline & \multicolumn{2}{|c|}{$\begin{array}{c}\text { Designing and execution } \\
\text { of construction works }\end{array}$} & $\begin{array}{c}\text { Execution } \\
\text { of construction works }\end{array}$ \\
\hline Number of proceedings & \multicolumn{2}{|c|}{44} & 6 \\
\hline Value & max & min \\
\hline Investor's budget & 662402696.94 PLN & 5141400.00 PLN & 137185144.16 PLN \\
\hline $\begin{array}{c}\text { Number } \\
\text { of offers submitted }\end{array}$ & 17 & 1 & 7.22 \\
\hline $\begin{array}{c}\text { The value } \\
\text { of offers }\end{array}$ & 513644042.91 PLN & 4298481.00 PLN & 106551145.79 PLN \\
\hline
\end{tabular}

\section{ANALYSIS OF SELECTED PROCUREMENT PROCEDURES}

\subsection{CRITERIA, THEIR TYPE AND WEIGHT}

In public procurement, the selection of the best bid in the tendering procedure for construction works is made on the basis of the evaluation of the submitted bids and after the contractors meet the conditions specified by the awarding entity in the tender documentation (Specification of Essential Terms of Contract). The basic instrument in the selection of the best offer in the public procurement procedure are the criteria adopted for the evaluation of offers [20]. The criteria can be defined by the ordering party with a certain freedom with the proviso that they are defined in an unambiguous manner and do not contradict other applicable regulations, including the PPL Act [24].

This article does not analyse the conditions that contractors applying for the contract must fulfil. Instead, attention was focused only on the criteria of offer evaluation. The general formula for the evaluation of offers can be defined as follows [10]:

$$
P=\sum_{i=1}^{n} N^{*} w_{1}
$$


where:

$\mathrm{P}$ - total number of points awarded to the offer, $\mathrm{N}$ - the value of the " $\mathrm{j}$ " offer, according to the "I" criterion, w - weight (importance) of the "I" criterion

In order to evaluate the offers, in all the analysed proceedings, the contracting entity used a point score taking into account the weight per cent of the previously determined criteria. It involves awarding the maximum number of points to the offer which is the most favourable due to the criterion examined, while the remaining offers receive fewer points. This method is used for both measurable and non-measurable criteria. If the most favourable criterion is the minimum, such as the lowest price or the shortest implementation period, then the formula has the following form:

$$
N=\frac{b}{t} * p
$$

where:

$\mathrm{N}$ - point score, $\mathrm{b}$ - value of the best offer according to criterion "i", $\mathrm{t}$ - value of the tested offer according to criterion "i", $\mathrm{p}$ - number of points

After analysing selected fifty tender procedures, it is possible to indicate 6 criteria used by the contracting entity. They include: gross price, completion date, warranty/guarantee, experience of the contractor's key personnel, time of track closures, and employment of workers under a contract of employment. The weights assigned to them in individual proceedings are shown in Figure 1 


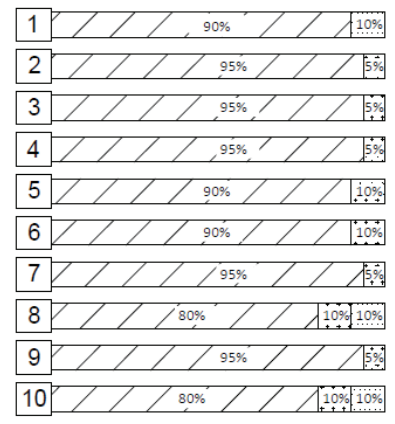

Cryterion:

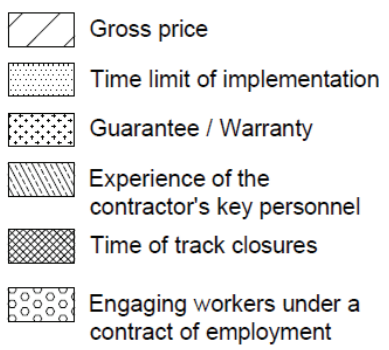

\begin{tabular}{|c|c|}
\hline 1 . & $/ / / 80 \% / / / 720$ \\
\hline & $/ / 60 \% / / 6+40 \%$ \\
\hline & $Z /{ }^{50 \%} / \lambda$ \\
\hline & 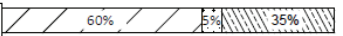 \\
\hline & $/, 60 \%, / \lambda\left(20.0 \% \omega^{*}+20\right.$ \\
\hline & $Z / Z, 90 \%, / Z$ \\
\hline & $/ /^{600 \%} / / \because 40 \%$ \\
\hline & $Z / / /^{90 \%} / Z$ \\
\hline & $Z / 60 \% / Z 1 \% 20 \% \%+1: 20 \%$ \\
\hline & $D / 60 \% / / / 7$ \\
\hline & 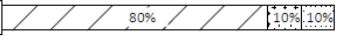 \\
\hline & 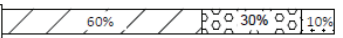 \\
\hline & 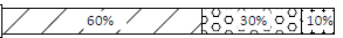 \\
\hline & 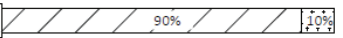 \\
\hline & $Z / / /^{80 \%}$ \\
\hline & $/ \quad 1+20 \%+20 \%$ \\
\hline & $/ / 60 \% / / \sigma^{20 \%}{ }^{20 \%+20 \%}$ \\
\hline & $l /{ }^{60 \%}{ }^{\prime} / / / x_{40 \%}$ \\
\hline & 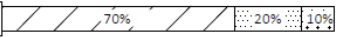 \\
\hline 30 & $Z / 60 \% / Z$ \\
\hline
\end{tabular}

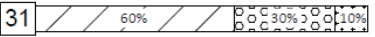

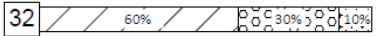

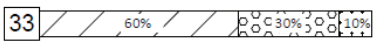

$34 Z /, 60 \%$ ' $/$ /

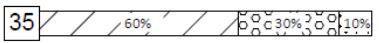

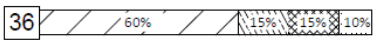

$37 / / 60 \% / / / 70 \%$ \%

$38 / /{ }^{60 \%} / / / 20 \%$.

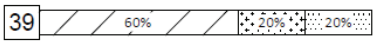

$40 / Z 60 \% / Z 720 \%$

$41 / / 60 \% / /$ 60\%

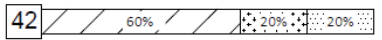

$43 \backslash / \gamma^{60 \%}, / \lambda^{6} \quad 40 \%$

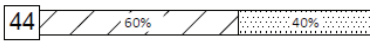

$45 / / /^{60 \%} / / 20 \%$ N $1220 \%$

$46 / / 60 \% / / 20 \%$

$47 / / 60 \% / / 30 \%$ i $10 \%$

$48 Z / / 20 \% / Z / 10 \%$

$49 / Z / / 90 \% / Z / 7+10 \%$

$50 / / /^{70 \%} / Z 20 \%$

Fig. 1. Percent of individual criteria in the analysed proceedings.

The previous practice of the company (on the basis of the tenders analysed) in announcing tender procedures reveals that at the selection of the contractor no more than three basic criteria were considered: gross price, completion date, guarantee / warranty [26]. They were applied as a result of limiting the possibility of using price as the only criterion for the evaluation of offers, introduced by the amendment of the Act of 29 August 2014 amending the Act - Public Procurement Law (Journal of Laws of 2014, item 1232). Apart from price, the contracting party was obliged to apply at least one more criterion related to the subject of the contract. In the next amendment to the PPL (of June 22, 2016), the share of the price criterion was limited to a maximum of $60 \%$ [25].

The legislator provided for the possibility of increasing the level of this criterion, even up to $100 \%$, stipulating, however, that in such a case the subject of the public procurement must be duly detailed and described. The amendment to the PPL and the investor's experience led to the introduction of new "qualitative" criteria previously not considered. This group includes: experience of the contractor's key personnel, time of track closures and engaging employees under a contract of employment.

When analysing Figure 1, the following relationships were observed: 
- "Gross price" criterion above $60 \%$, which could have resulted from the proper specification and description of the subject of the contract, which is permitted by the PPL Act, or the announcement of a tender procedure even before the amendments to the Public Procurement Law from 22 June 2016 were introduced.

- In 20 out of 50 tender procedures considered, only one non-price criterion was applied.

- In 29 out of 50 tendering procedures considered, at least two non-price criteria were used.

- In 15 of the 50 tendering procedures under consideration, at least one qualitative tender criterion was used, such as: experience of the contractor's key staff, time of track closures and engaging employees under a contract of employment.

The use of individual criteria in the considered proceedings has been presented in Table 2 .

Table 2. Weights assigned to criteria and the frequency of their application

\begin{tabular}{|c|c|c|c|c|}
\hline Criterion & $\begin{array}{c}\text { Weight } \\
\text { min. }\end{array}$ & Weight max. & Weight mid. & $\begin{array}{c}\text { Number of proceedings } \\
\text { in which the criterion was } \\
\text { applied }\end{array}$ \\
\hline Gross price & $50 \%$ & $95 \%$ & $70.50 \%$ & 50 \\
\hline $\begin{array}{c}\text { Time limit for } \\
\text { implement. }\end{array}$ & $10 \%$ & $40 \%$ & $19.79 \%$ & 24 \\
\hline $\begin{array}{c}\text { Guarantee / Warranty } \\
\text { Experience of the } \\
\text { contractor's key } \\
\text { personnel }\end{array}$ & $5 \%$ & $40 \%$ & $14.39 \%$ & 5 \\
\hline $\begin{array}{c}\text { Time of track closures } \\
\text { Engaging workers under } \\
\text { a contract of } \\
\text { employment }\end{array}$ & $15 \%$ & $40 \%$ & $20.00 \%$ & 5 \\
\hline
\end{tabular}

As Table 2 reveals, in addition to the price criterion, which has always been applied with the highest weight, the criteria of time limit for implementation and of guarantee are very often used. In six proceedings, the criterion of engaging employees under a contract of employment was introduced, for which the contracting authority assumed in each case a weight of $30 \%$. The weight of the criterion dedicated to railway works, that is the time of track closures, ranged from $15 \%$ to $40 \%$.

Further analysis of tender procedures concerned the impact of the adopted criteria on the selection of the most favourable offer submitted. For this purpose, it was decided to analyse the bids in terms of the lowest price and the most advantageous offer, which resulted from the algorithm (the point 
method mentioned above) used by the contracting entity. Table 3 presents in detail the criteria and their weights applied. The results revealed that only in 4 out of 50 procedures the most advantageous bid was not the one with the lowest price.

Table 3. Weights assigned to criteria in procedures the most advantageous bid was not the one with the lowest price

\begin{tabular}{|c|c|c|c|c|}
\hline \multirow{2}{*}{ Criterion } & \multicolumn{4}{|c|}{$\begin{array}{c}\text { Proceedings* } \\
\text { [weight] }\end{array}$} \\
\cline { 2 - 5 } & 15 & 30 & 38 & 47 \\
\hline Gross price & $60 \%$ & $60 \%$ & $60 \%$ & $60 \%$ \\
\hline Guarantee / Warranty & $20 \%$ & $10 \%$ & - & \\
\hline Time of track closures & $20 \%$ & $15 \%$ & - & \\
\hline Time limit for implementation & - & $15 \%$ & $20 \%$ & $30 \%$ \\
\hline Experience of the contractor's key personnel & - & - & $20 \%$ & $10 \%$ \\
\hline
\end{tabular}

In each of these tender procedures, the weight for the price criterion was $60 \%$ and at least two nonprice criteria were applied. Noteworthy is the criterion dedicated to railway works, namely the time of track closures, which were applied in two out of four indicated tender procedures.

This criterion determines the availability of a section of a railway track during the implementation of works to carry out transport work. What is assessed is the number of hours that the contractor is planning to use during 24-hour closures. These are related to the accepted technology of works, assumed work schedule, as well as human and hardware resources available to the contractor. The time of track closures is calculated taking into account the fact that for each track it is counted independently, and that the modernized railway line must be available to the rolling stock (two-way closures are not allowed on any of the routes). The rules of organization and provision of track closures are described in the relevant Instructions of the employer [1].

\subsection{NUMBER OF BIDDERS PARTICIPATING IN PROCEEDINGS AGAINST THE VALUE OF THE CONTRACT}

Figure 2 shows the number of offers submitted depending on the value of the order. It was observed that the budget of the contracting entity is not a determinant of greater interest in the tender or an increase in the number of bidders participating in it. When trying to define a dependency, it seems that the higher the value of the order, the smaller the number of interested contractors. It may result 
from the requirements that must be met by a potential contractor submitting an offer covering a wide range of design and/or construction works.

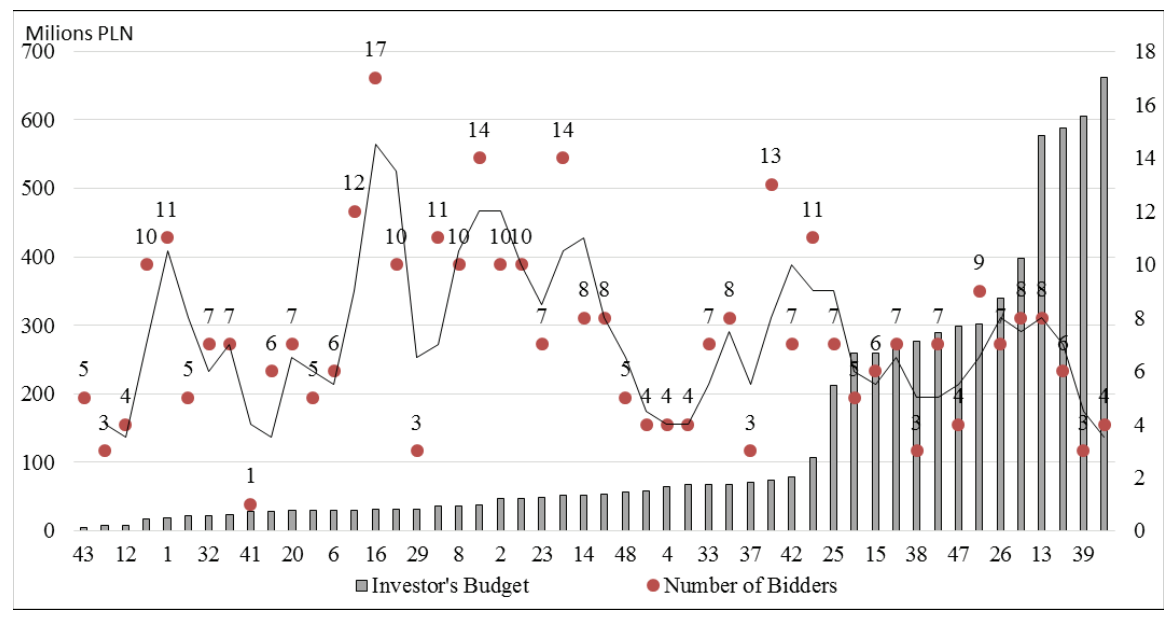

Fig. 2. Number of bidders depending on the budget of the contracting entity

Figure 3 shows the number of offers submitted depending on the value of the order, in chronological order, starting from proceedings for which the opening of bids took place at the earliest.

A trend line was drawn and it was observed that the number of bidders was decreasing along with the subsequent announced proceedings. It can be assumed that the construction market in the railway industry is slowly getting saturated.

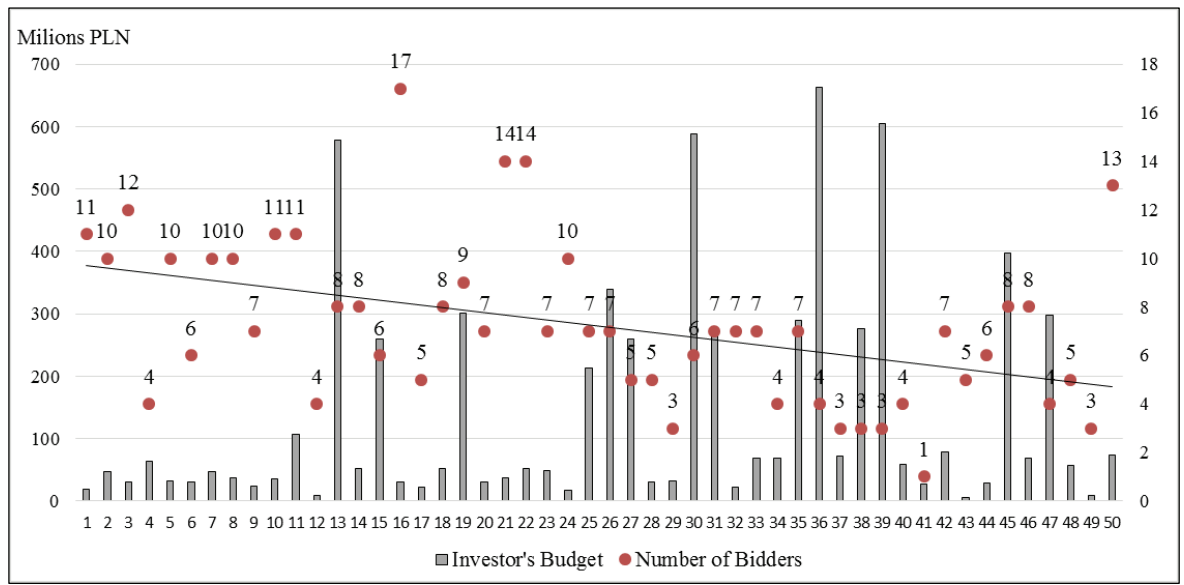


Fig. 3. Number of bidders against the contracting entity's budget (in chronological order)

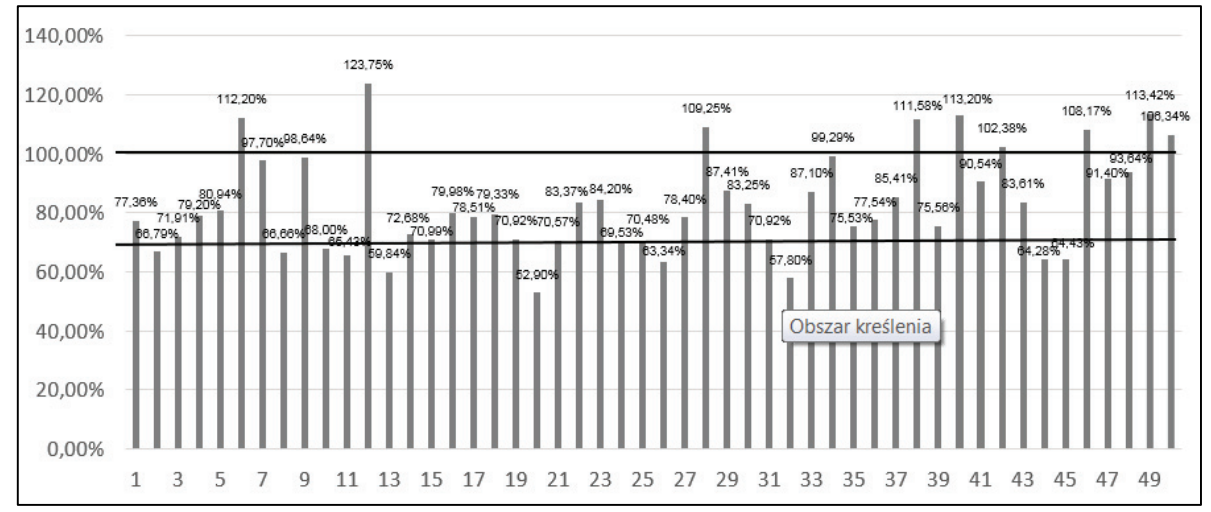

Fig. 4. The ratio of the value of the best offer to the value of the order

Figure 4 presents the values of the most advantageous price offers, submitted in the tender proceedings under consideration. In addition, two horizontal lines were drawn on the graph: One at the level of $100 \%$, which shows the value of the budget of the ordering party in the context of the most advantageous bid. It can be noticed here that 8 of the most advantageous offers for the 50 orders analysed exceeded the budget of the contracting entity, which could be the basis for the annulment of the proceedings. The line, at the level of $70 \%$ (excluding tax) corresponding to the value below which the contracting entity may ask the contractor to explain such a low offer price. In the absence of explanations or their being unacceptable, the offer may be rejected without further justification [24]. 30 of the 50 most advantageous offers are in the range (70\%-100\%) of the contract value.

\section{Conclusions}

The tendering procedures for construction works by PKP PLK S.A. announced are a complex process and selecting contractors may take up to several months.

The analysis of tender proceedings based on information from the tender opening procedure is reflected in the impact of the amendment to the PPL Act [25]. Since the introduction of the revised provisions of the Act, there has been a noticeable change of the contracting entity in determining the criteria for the selection of contractors. This applies to both maintaining the maximum price criterion level $(60 \%)$ as well as the introduction and application of new criteria relating to the subject of the contract, based on a wider assessment of, among others, quality, social, 
environmental or innovative aspects. In the selection of the contractor in the tender procedures under consideration, only in four (after detailed analysis) the impact on the selection of the most advantageous offer was affected by the non-price criteria. This result is not highly satisfactory. It turns out that despite the use of non-price criteria, the offer with the lowest price is often the most advantageous one.

It should be noted that the analysis included also the tenders which had been announced before the amendment of the PPL Act of 2016 and they belong to the first ones implemented after the changes. The contracting entity was just starting to introduce the criteria that could have a significant impact on the result of the tender. It also seems that they understand the need to improve the bid evaluation process. This fact is confirmed by the following criteria: experience of the contractor's key personnel or the one dedicated to railway works - time of track closures, which were used in the evaluation of bids in tenders where the offer with the lowest price was not the most advantageous.

The application of appropriate criteria relating to the subject of the contract is not easy for the contracting authority and, as demonstrated by the analysis, it may have a significant impact on the selection of the most advantageous offer. It should also be noted that some of the potential contractors (in $40 \%$ of the orders analysed) may not have been selected due to the too low or too high offer. The numerous participation of bidders, according to the analysis of selected tenders (max 17, average 7), does not depend on the size / value of the works ordered and may be reflected in other conditions not covered in this paper. When analysing the number of offers submitted in the period under consideration, a downward trend is noticed. It may be affected by the current situation of the construction sector [2] and entering the next phase of the current EU perspective, from which individual tenders are financed [22].

\section{REFERENCES}

1. Annex to Resolution No. 884/2017 of the Management Board of PKP Polskie Linie Kolejowe S.A. of 28 August 2017: Instruction Ir-19 "Rules for the organization and provision of track closures", Warsaw, Poland, 2017.

2. "Demand for work in the third quarter of 2017", Monit. Labor Market, Central Statistical Office, Warsaw, Poland, 2017.

3. Directive 2004/18 / EC of the European Parliament and of the Council of March 31, 2004 on the coordination of procedures for the award of public works, supplies and services contracts, Journal of Laws of the EU L of 30 April 2004.

4. B. Hola, "Identification and evaluation of processes in a construction enterprise. Archives of Civil and Mechanical Engineering, 15(2): 419-426, 2015.

5. B. Hola, M. Szostak: "Analysis of the state of the accident rate in the construction industry in European Union countries, Archives of Civil Engineering, 61(4):19-34, 2015.

6. https://zamowienia.plk-sa.pl/, archived on 1.042017. 
7. M. Juszczyk, R. Kozik, A. Leśniak, E. Plebankiewicz, E., K. Zima, "Errors in the Preparation of Design documentation in Public Procurement in Poland", Procedia Engineering, 85:283-292, 2014.

8. K. Kaczorek, M. Krzemiński, N. Ibadov, "The problem of choosing risk management methodology at the example of railway construction”, MATEC Web of Conf. vol 117 RSP 2017 - XXVI R-S-P Seminar Theoretical Foundation of Civil Engineering p 00073, 2017.

9. J. Kowalski, M. Połoński, „Identyfikacja ryzyka wynikającego z wpływu interesariuszy na realizację inwestycji kolejowych w Polsce”, Acta Scientiarum Polonorum Architectura, 16 (4):83-92, 2017.

10. R. Kozik, A. Leśniak, E. Plebankiewicz, K. Zima, „Dokumentacja przetargowa i kosztowa w budowlanym procesie inwestycyjnym”, Wydawnictwo Politechniki Krakowskiej, Cracow, Poland, 2015.

11. M. Krzemiński, "Optimization of work schedules executed using the flow shop model, assuming multitasking performed by work crews", Archives of Civil Engineering, 63(4): 3-19, 2017.

12. D. Kuchta, D. Skorupka, "International Journal of Computers Communications \& Control", 9(5): 584-592, 2014.

13. A. Leśniak, „Classification of the Bid/No Bid Criteria - Factor Analysis”, Archives of Civil Engineering, LXI, 4:7990, 2015.

14. A. Leśniak, "Supporting contractors' bidding decision: RBF neural networks application", ICNAAM, AIP Conference Proceedings, 1738, 2016.

15. A. Leśniak, E. Plebankiewicz, „Modeling the Decision-Making Process Concerning Participation in Construction Bidding", Journal of Management in Engineering, 31 (2): 04014032, 2015.

16. A. Leśniak, E. Plebankiewicz, K. Zima, "Design and build procurement system-contractor selection”, Archives of Civil Engineering, 58(4): 463-476, 2012.

17. A. Massel, "Ewolucja stanu infrastruktury kolejowej w Polsce w latach 1990-2014”, Logistyka, 4/2014:2182-2190, Poznan, Poland, 2014.

18. "Master plan for rail transport in Poland until 2030", Ministry of Infrastructure, Warsaw, Poland, 2008.

19. E. Plebankiewicz, K. Zima, D. Wieczorek, "Life cycle cost modelling of buildings with consideration of the risk.", Archives of Civil Engineering, 62(2): 149-166, 2016.

20. E. Plebankiewicz, R. Kozik, "The transformation of the tender evaluation process in public procurement in Poland", IOP Publishing Conference Series: Materials Science and Engineering, 251 (1): 012042, 2017.

21. M. Połoński, J. Kowalski, "The identification of hazards concerning the character of construction works on railway sites in Poland", Technical Transactions, Civil Engineering, 5: 47-55, Wydawnictwo Politechniki Krakowskiej, Cracow, Poland, 2017.

22. Resolution No. 186/2017 of the Council of Ministers of December 4, 2017 - update of the National Railway Program until 2023, Warsaw, Poland, 2017.

23. "Statute of PKP Polskie Linie Kolejowe Spółka Akcyjna", attachment to the Resolution No. 10 of the Ordinary General Meeting of PKP Polskie Linie Kolejowe S.A. of June 15, Warsaw, 2015.

24. The Act of 29 January 2004 - Public Procurement Law, Journal of Laws of 2017 item 1579, 2017

25. The Act of 22 June 2016 amending the Act - Public Procurement Law and some other acts, Journal of Laws item 1020, 2016;

26. www.bip.plk-sa.pl, archived on 13.01.2018

\section{LIST OF FIGURES AND TABLES:}

Fig. 1. Percent of individual criteria in the analysed proceedings.

Rys. 1. Udział poszczególnych kryteriów w analizowanych postępowaniach

Fig. 2. Number of bidders depending on the budget of the contracting entity

Rys. 2. Liczba oferentów w zależności od budżetu Zamawiającego

Fig. 3. Number of bidders against the contracting entity's budget (in chronological order)

Rys. 3. Liczba oferentów na tle budżetu Zamawiającego (w kolejności chronologicznej)

Fig. 4. The ratio of the value of the best offer to the value of the order

Rys. 4. Stosunek wartości najkorzystniejszej oferty do wartości zamówienia

Tab. 1. Characteristics of the proceedings discussed 
Tab. 1. Charakterystyka omawianych postępowań

Tab. 2. Weights assigned to criteria and the frequency of their application

Tab. 2. Wagi przypisywane kryteriom i częstość ich stosowania

Tab. 3. Weights assigned to criteria in procedures the most advantageous bid was not the one with the lowest price

Tab. 3. Wagi przypisywane kryteriom w postepowaniach gdy najkorzystniejsza oferta nie była ofertą z najniższą ceną 


\section{ANALIZA KRYTERIÓW WYBORU WYKONAWCY ROBÓT BUDOWLANYCH W PRZEDSIĘWZIĘCIACH KOLEJOWYCH}

Stowa kluczowe: kryteria przetargowe, zamawiający publiczny, infrastruktura kolejowa

\section{STRESZCZENIE:}

Wybór Wykonawcy robót budowlanych wymaga szczególnej staranności zamawiających publicznych. Sposób przeprowadzenia procedury przetargowej jak i zawartość dokumentów przetargowych określone są $\mathrm{w}$ Ustawie Prawo zamówień publicznych z dnia 29 stycznia 2004 r. (Dz. U. z 2015 r. poz. 2164, ze zm.). Do największych zamawiających publicznych w Polsce należą zamawiający sektorowi - podmioty zdefiniowane w art. 3 Ustawy Pzp.

Celem pracy jest analiza zamówień publicznych na wykonanie lub zaprojektowanie i wykonanie robót budowlanych, związanych z przebudową, budową i rewitalizacją linii kolejowych rozstrzyganych po nowelizacji ustawy Pzp dnia 22 czerwca 2016 r. Szczególną uwagę zwrócono na stosowane kryteria przetargowe oraz wymagania stawiane potencjalnym wykonawcom robót w zakresie infrastruktury kolejowej.

Rozważana grupa dotyczyła postępowań na roboty budowlane w przedsięwzięciach kolejowych, w których zamawiającym były PKP PLK S.A. Przy ich wyborze uwzględniono następujące warunki: otwarcie kopert w przetargu na roboty budowlane nastąpiło w dniach: 1.08.2016r. - 30.03.2017r.; ogłoszenie z zamówieniu było ogłaszane w trybie przetargu; budżet inwestorski zamawiającego opiewał na min. $1 \mathrm{mln}$ zł brutto;. Analizie poddano 50 protokołów $\mathrm{z}$ otwarcia ofert, które zostały pobrane ze strony internetowej zamawiającego.

Po analizie wybranych pięćdziesięciu postępowań przetargowych można wskazać sześć różnych stosowanych przez zamawiającego kryteriów. Oprócz kryterium ceny, które było zawsze przyjęte z najwyższa wagą, często stosowane były dwa kryteria: gwarancja/rękojmia (41 postepowań, waga do $5 \%$ do $40 \%$ ), termin realizacji (24 postępowań, waga do $10 \%$ do $40 \%$ ). W 6 postepowaniach wprowadzono kryterium ,zatrudnienia pracowników na podstawie umowy o pracę" dla którego zamawiający, w każdym z przypadków przyjmował wagę $30 \%$. Kryterium dedykowane robotom kolejowym - czas zamknięć torowych, zastosowano w 5 postępowaniach z wagą od $15 \%$ do $40 \%$. W $8 \%$ analizowanych zamówieniach zastosowanie kryteriów pozacenowych doprowadziło do wyboru oferty, w której proponowana cena nie była najniższa wśród składanych ofert. W każdym z nich, waga dla kryterium ceny stanowiła $60 \%$ i zastosowano dodatkowo co najmniej dwa kryteria pozacenowe

Analizując liczbę składanych ofert w zależności od wartości zamówienia zaobserwowano, iż budżet zamawiającego nie jest wyznacznikiem większego zainteresowania przetargiem i wzrostu liczby uczestniczących w nim oferentów.

Od wprowadzenia znowelizowanych zapisów ustawy] zauważalna jest zmiana Zamawiającego w określaniu kryteriów wyboru Wykonawców. Dotyczy to, zarówno utrzymania maksymalnego poziomu kryterium ceny $(60 \%)$ jak również wprowadzenia i stosowania nowych kryteriów odnoszących się do przedmiotu zamówienia, opartych na szerszej ocenie m.in. jakości, aspektów społecznych, środowiskowych czy innowacyjnych. Zastosowanie właściwych kryteriów odnoszących się do przedmiotu zamówienia nie jest łatwe dla Zamawiających, a jak wykazała analiza mogą mieć one wpływ na wybór najkorzystniejszej oferty. 